\title{
APA, BAGAIMANA, DAN DAMPAK REKSA DANA
}

\author{
Kiki Nindya Asih \\ Wahyu Pratomo ${ }^{1}$
}

\section{PENDAHULUAN}

$\mathrm{P}$ roduk reksa dana (mutual fund) akhir-akhir ini mendapat cukup banyak perhatian dengan perkembangannya yang fenomenal khususnya dalam 12 bulan terakhir² . Perkembangan fenomenal ini tercermin dari peningkatan jumlah nasabah (pemegang unit penyertaan reksa dana), dana kelolaan, dan produk reksa dana yang beredar di pasar ${ }^{3}$. Sampai dengan bulan Desember 2002, jumlah account investor reksa dana tercatat sebesar 125.820 account (143,2\%, y-o-y), sementara dana kelolaan secara tahunan melonjak 252,8\% menjadi Rp56,1 triliun. Rasio dana kelolaan terhadap DPK meningkat tajam, dari hanya 2\% di awal tahun 2002 menjadi 7\% pada bulan Desember 2002 ${ }^{4}$. Sementara itu, dari

\section{Grafik 1. Perkembangan DPK dan Kelolaan MI}

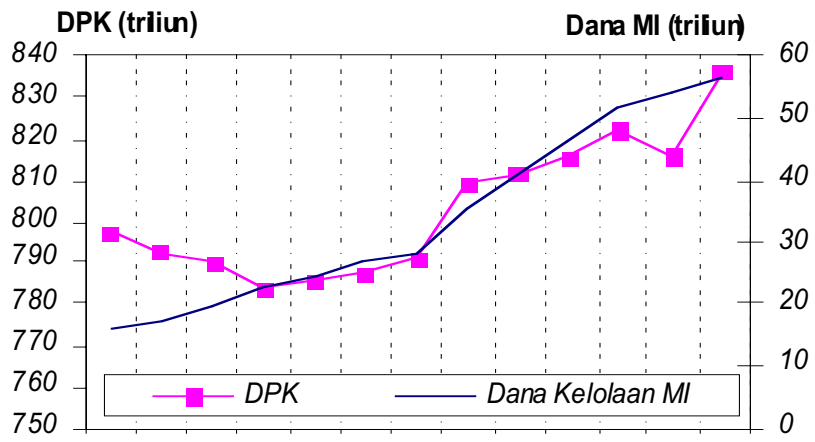

1 Penulis adalah peneliti ekonomi di Bagian Analisis dan Perencanaan Kebijakan, Direktorat Riset Ekonomi dan Kebijakan Moneter. Terima kasih penulis sampaikan kepada rekan-rekan dari bagian SMON-DSM, PTPU-DPM, DPNP, DPmB2, DPwB2, dan internal DKM atas saran, masukan, komentar, berikut data dan informasi yang sangat berharga.

2 Reksa dana (mutual fund) adalah sertifikat yang menjelaskan bahwa pemiliknya menitipkan sejumlah uang kepada pengelola reksa dana untuk digunakan sebagai modal berinvestasi di pasar uang atau pasar modal sesuai dengan kebijakan investasi yang dipilih. Reksa dana merupakan produk pasar modal (UU No. 8 tahun 1995). Reksa dana diterbitkan oleh perseroan yang telah memperoleh ijin dari Bapepam.

3 Dana kelolaan MI digunakan sebagai proksi dana kelolaan reksa dana. Sebenarnya data dana kelolaan MI terdiri dari dana kelolaan reksa dana dan discretionary fund (untuk kepentingan nasabah institusi seperti Dana Pensiun, Asuransi ataupun Yayasan). Hal ini dilakukan karena statistik pasar modal belum memisahkan keduanya.

4 Rasio ini sebenarnya masih relatif rendah bila dibandingkan dengan rasio untuk Malaysia (sekitar 16\%), India dan Australia (sekitar 30\%). 
4 jenis reksa dana yang ditawarkan ke pasar ${ }^{5}$, saat ini terdapat 131 macam produk dari hanya 25 macam produk pada awal reksa dana diperkenalkan di tahun 1996.

Walaupun portfolio tiap produk reksa dana adalah unik, perkembangannya yang pesat ini antara lain didorong oleh (i) meningkatnya intensitas penerbitan maupun perdagangan obligasi pemerintah di pasar sekunder dalam dua tahun terakhir, (ii) kecenderungan menurunnya suku bunga simpanan perbankan, (iii) tidak dibatasinya penempatan reksa dana yang berbasis obligasi pemerintah oleh Bapepam ${ }^{6}$, (iv) dibebaskannya PPh final atas kupon dan diskonto produk reksa dana (PP No. 6/2002)7, (v) keterlibatan bank dalam menjual reksa dana yang seolah 'membungkus' produk pasar modal menjadi produk perbankan ${ }^{8}$.

Tabel 1. Perubahan Posisi Kepemilikan Obligasi Pemerintah

\begin{tabular}{|l|r|r|r|r|}
\hline \multicolumn{1}{|c|}{ Pemilik } & Jan 2002 & Persentase & Des 2002 & Persentase \\
\hline Departemen Keuangan & $\mathbf{8 7 7 . 5 4 5}$ & $\mathbf{0 , 2 2}$ & $\mathbf{8 7 2 . 5 4 5}$ & $\mathbf{0 , 2 2}$ \\
Bank Rekapitalisasi & $\mathbf{3 5 5 . 6 2 2 . 5 4 0}$ & $\mathbf{8 9 , 6 2}$ & $\mathbf{3 3 4 . 5 7 3 . 9 5 6}$ & $\mathbf{8 4 , 9 0}$ \\
BUMN Rekap & 233.520 .212 & 58,85 & 228.176 .234 & 57,90 \\
BUSN Rekap & 18.564 .349 & 4,68 & 22.646 .557 & 5,75 \\
Bank Take Over & 102.307 .529 & 25,78 & 82.538 .678 & 20,95 \\
Bank Pembangunan Daerah & 1.230 .450 & 0,31 & 1.212 .487 & 0,31 \\
Bank Non Rekapitalisasi & $\mathbf{2 6 . 7 0 6 . 2 3 5}$ & $\mathbf{6 , 7 3}$ & $\mathbf{1 3 . 8 2 9 . 2 3 4}$ & $\mathbf{3 , 5 1}$ \\
Sub Registry & $\mathbf{1 3 . 5 8 4 . 0 8 7}$ & $\mathbf{3 , 4 2}$ & $\mathbf{4 4 . 7 8 2 . 1 4 7}$ & $\mathbf{1 1 , 3 6}$ \\
Asuransi & 4.158 .511 & 1,05 & 6.512 .792 & 1,65 \\
Reksa Dana & 2.317 .965 & 0,58 & 35.719 .912 & 9,06 \\
Dana Pensiun & 170.750 & 0,04 & 360.411 & 0,09 \\
BPPN/Perbankan & 6.671 .328 & 1,68 & 1.908 .124 & 0,48 \\
Corporate & 113.177 & 0,03 & 71.880 & 0,02 \\
Sekuritas & 147.170 & 0,04 & 133.603 & 0,03 \\
Yayasan & 3.000 & 0,00 & & 0,00 \\
Perorangan & 2.186 & 0,00 & - & 0,00 \\
Lainnya & 0 & 0,00 & 75.425 & 0,02 \\
SUB TOTAL & $\mathbf{1 0 6 . 7 9 0 . 4 0 7}$ & $\mathbf{1 0 0 , 0 0}$ & 394.057 .882 & $\mathbf{1 0 0 , 0 0}$ \\
\hline
\end{tabular}

5 Jenis-jenis reksadana: reksadana pasar uang, reksadana pendapatan tetap, reksadana saham, dan reksadana campuran. Informasi yang lebih mendalam dapat dilihat pada lampiran.

6 Obligasi korporasi dibatasi hanya 10\% dari Nilai Aktiva Bersih reksa dana pada setiap saat.

7 Khususnya bagi produk reksa dana yang berumur kurang dari 5 tahun. Manajer Investasi menyiasati hal ini dengan terus memperbaharui produknya dan secara otomatis memindahkan rekening nasabahnya ke produk yang lebih baru pada saat produk reksana mencapai usia 5 tahun.

8 Peran perbankan di pasar modal diatur dengan ketentuan SK Direksi BI No. 25/97/KEP/DIR dan SE BI No. 25/1/BPPP tanggal 17 November 1992 tentang Penyertaan Modal dan Pemilikan Saham oleh Bank. Dalam ketentuan dimaksud, keikutsertaan bank dapat digolongkan sebagai (1) pendiri perusahaan efek, (2) penyedia jasa sebagai bank kustodian dan atau agen penjual reksa dana dalam outlet terpisah, dan (3) investor. 
Tabel 2. Data Kepemilikan Obligasi Pemerintah dalam Sub-registry

\begin{tabular}{|l|r|r|r|r|}
\hline \multirow{2}{*}{ Bidang Usaha } & \multicolumn{2}{|c|}{ Januari 2002} & \multicolumn{2}{c|}{ Desember 2002 } \\
\cline { 2 - 5 } & Nilai Nominal & Persentase & Nilai Nominal & Persentase \\
\hline Asuransi & 4.158 .511 .000 .000 & 30,61 & 6.512 .792 .000 .000 & 14,54 \\
Reksa Dana & 2.317 .965 .000 .000 & 17,06 & 35.719 .912 .000 .000 & 79,76 \\
Dana Pensiun & 170.750 .000 .000 & 1,26 & 360.411 .000 .000 & 0,80 \\
Perbankan & 6.671 .328 .000 .000 & 49,11 & 1.908 .124 .000 .000 & 4,26 \\
Corporate & 113.177 .000 .000 & 0,83 & 71.880 .000 .000 & 0,16 \\
Sekuritas & 147.170 .000 .000 & 1,08 & 133.603 .000 .000 & 0,30 \\
Yayasan & 3.000 .000 .000 & 0,02 & - & - \\
Perorangan & 2.186 .000 .000 & 0,02 & - & - \\
Lain-lain & - & - & 75.425 .000 .000 & $\mathbf{1 0 0 , 0 0}$ \\
Total & $\mathbf{1 3 . 5 8 4 . 0 8 7 . 0 0 0 . 0 0 0}$ & $\mathbf{1 0 0 , 0 0}$ & $\mathbf{4 4 . 7 8 2 . 1 4 7 . 0 0 0 . 0 0 0}$ & \\
\hline
\end{tabular}

Perkembangan ini terutama dimotori oleh reksa dana dengan underlying portfolio obligasi pemerintah khususnya obligasi rekapitalisasi perbankan. Hal ini antara lain tercermin dari Tabel 1 dan 2 yang menunjukkan perubahan posisi kepemilikan obligasi pemerintah (termasuk obligasi rekap) yang sangat signifikan, dari perbankan ke perusahaan reksa dana. Dari Tabel 1 terlihat jelas bahwa persentase kepemilikan obligasi pemerintah oleh perusahaan reksa dana meningkat dari 0,6\% di bulan Januari 2002 menjadi 9,1\% di bulan Desember tahun yang sama. Persentase kenaikan kepemilikan ini $(8,5 \%)$ hampir setara dengan persentase penurunan kepemilikan obligasi pemerintah yang terjadi pada bank rekap, bank non-rekap, dan BPPN/perbankan $(9,1 \%)$.

Dalam tulisan ini, pertama-tama akan dibahas mengenai mekanisme transaksi reksa dana melalui perbankan. Bagian selanjutnya akan membahas tentang apa dan bagaimana dampak potensial dari perkembangan reksa dana ini terutama terhadap (individu dan industri) perbankan, (indikator besaran) moneter dan sektor pemerintah. Hanya saja, patut dicatat bahwa tulisan ini tidak dimaksudkan sebagai sebuah produk final, melainkan sebuah kajian awal sebagai dasar studi yang lebih mendalam dan komprehensif.

9 Dalam tulisan ini-bila tidak disebutkan secara khusus—-kata 'bank' merujuk pada bank sebagai agen penjual.

10 Manajer Investasi berada dalam pengawasan otorita pasar modal dan tunduk pada ketentuan pasar modal. 


\section{PERAN (INDIVIDUAL) BANK DALAM TRANSAKSI REKSA DANA}

Secara umum peran perbankan yang terkait dengan reksa dana adalah sebagai bank kustodian dan agen penjual (selling agent) dari berbagai produk reksa dana yang dirilis oleh Manajer Investasi (pengelola reksa dana) ${ }^{910}$. Walaupun sama-sama berfungsi sebagai selling agent, implikasi transaksi reksa dana yang dilakukan oleh bank akan berbeda-beda. Hal ini banyak bergantung pada kesepakatan pihak bank dengan Manajer Investasi (pengelola reksa dana yang selanjutnya disingkat dengan MI), dan juga jenis bank-nya (bank non-rekap atau rekap).

Minimal terdapat dua bentuk praktek transaksi reksa dana melalui perbankan yang dapat diidentifikasi. Pertama, perbankan murni hanya bertindak sebagai agen penjual reksa dana (dan atau bank kustodian) ${ }^{11}$, di mana mereka memperoleh fee dari MI untuk menjalankan peran tersebut. Kedua, perbankan bertindak sebagai selling agent produk reksa dana dari MI yang underlying atau portfolio-nya dalam bentuk obligasi pemerintah yang dijual oleh bank yang bersangkutan (atau diistilahkan sebagai product mix). Sebagian besar bank yang terlibat dalam transaksi reksa dana hanya menjalankan peran selling agent, sementara salah satu bank rekap merupakan pemain pertama dan utama dari sedikit bank yang melakukan product mix.

Dua buah skema di bawah ini mencoba menggambarkan mekanisme transaksi reksa dana dengan underlying obligasi rekap melalui perbankan ${ }^{12}$. Di sini dilakukan simplifikasi bahwa tidak ada fresh money dari masyarakat (tidak ada calon pembeli reksa dana yang datang ke counter bank dengan membawa uang tunai) dan dana milik masyarakat yang digunakan untuk membeli reksa dana berasal dari simpanannya di bank penjual reksa dana (proses kanibal)

11 Untuk menjadi bank kustodian, bank harus mengajukan permohonan perijinan ke Bapepam. Bank dapat menjadi bank kustodian a/d SE BI No. 29/35/UPPB tanggal 31 Desember 1996. Bank kustodian adalah Pihak yang memberikan jasa penitipan kolektif dan harta lainnya yang berkaitan dengan Efek. Sedangkan Pihak yang dapat melaksanakan kegiatan usaha sebagai Kustodian adalah LPP, Perusahaan Efek (a.l. Penjamin Emisi, Perantara Pedagang Efek, dan Manajer Investasi), atau Bank Umum yang telah mendapat persetujuan dari Bapepam. Sampai dengan 30 April 2002, jumlah Bank Kustodian yang telah mendapat persetujuan dari Bapepam sebanyak 21 Bank Kustodian. Lembaga Penyimpanan dan Penyelesaian (LPP) adalah pihak yang menyelenggarakan kegiatan Kustodian sentral bagi Bank Kustodian, Perusahaan Efek, dan Pihak lain. Bapepam telah memberikan 1 izin usaha Lembaga Penyimpanan dan Penyelesaian: PT Kustodian Sentral Efek Indonesia (KSEI), PT KSEI mendapatkan izin usaha pada tanggal 11 Nopember 1998. Lembaga tersebut melaksanakan fungsi penyimpanan dan penyelesaian yang sebelumnya dikerjakan oleh PT Kliring Depositori Efek Indonesia (PT KDEI).

12 Skema selayaknya dipandang dalam kerangka dinamis atau flow. 


\section{Skim (pure) Selling Agent}

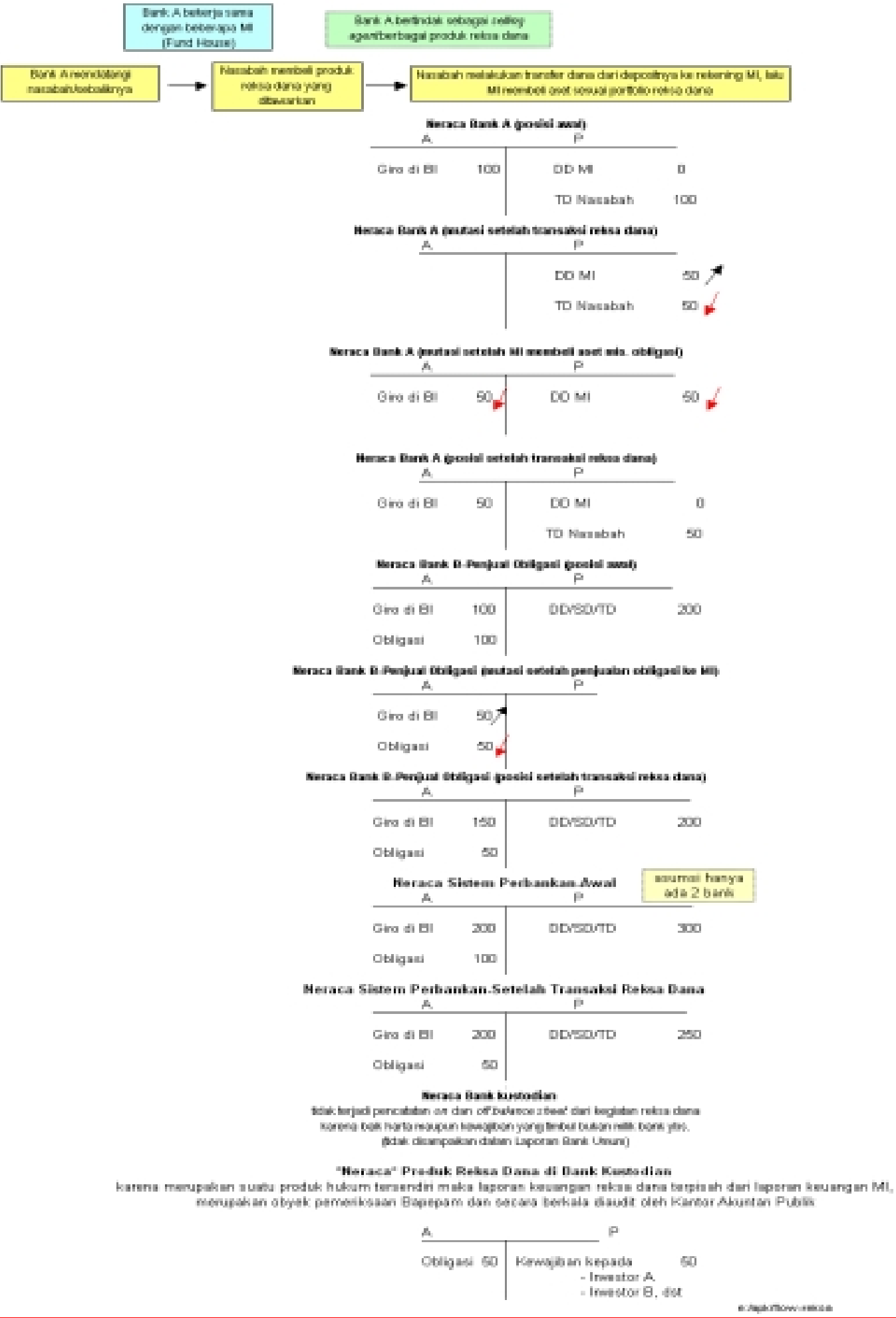




\section{Skim Selling Agent - Product Mix Approach $)^{13}$}

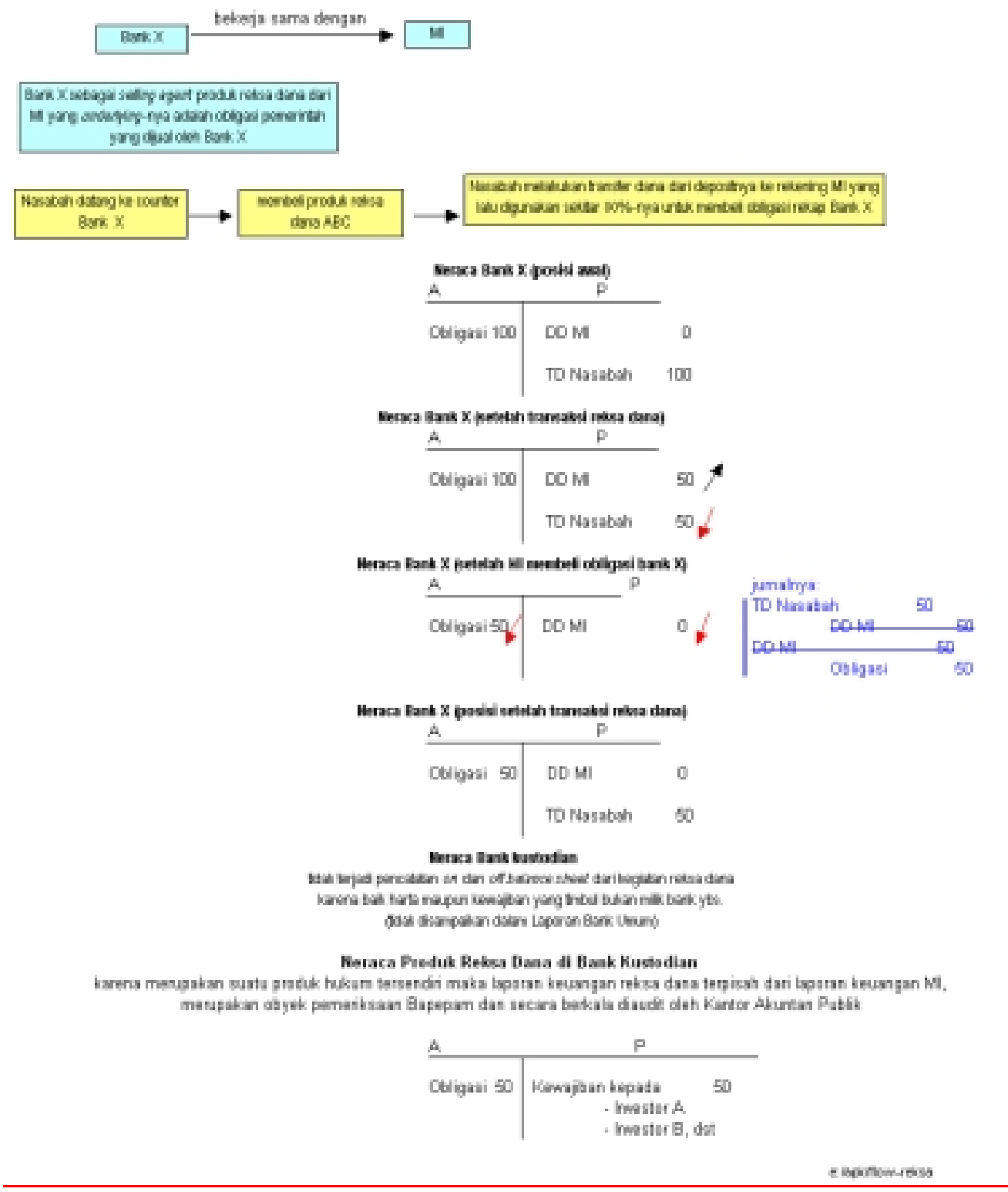

13 Besarnya kewajiban MI untuk membeli obligasi milik Bank sangat bervariasi dan tergantung pada perjanjian antar keduanya. 


\section{DAMPAK (POTENSIAL) PERKEMBANGAN REKSA DANA}

Meningkatnya intensitas transaksi reksa dana melalui perbankan mempunyai sejumlah dampak riil dan potensial dari kacamata (individu dan industri) perbankan, moneter, dan keuangan pemerintah.

\section{Perbankan}

Mekanisme di atas cukup jelas menggambarkan bahwa dengan murni bertindak sebagai selling agent, bank di satu sisi membuka peluang untuk menambah pendapatan (fee based income) dari kerja sama dengan Manajer Investasi. Di sisi lain, langkah bank ini dapat dipandang sebagai bentuk defense strategy. Dalam artian, selain menyediakan outlet alternatif penanaman dana dan mendapat tambahan pendapatan, bank sekaligus berupaya meng-'keep' nasabah besar (prime customer) agar tidak berpindah ke bank lain seiring dengan meningkatnya permintaan nasabah akan produk penanaman dana alternatif dengan return yang cukup tinggi di tengah-tengah kecenderungan penurunan suku bunga instrumen moneter dan produk perbankan.

Bagi bank yang melakukan pendekatan product mix, transaksi reksa dana memberi peluang kepada mereka untuk merestrukturisasi komponen neraca mereka ${ }^{14}$, dengan cara menyelaraskan maturity dan repricing profile antara sisi aktiva-pasiva bank ${ }^{15}$. Keterlibatan bank dalam transaksi jenis ini juga berpotensi mengurangi cost of funds bank mengingat sebagian besar dana pihak ketiga yang berpindah ke produk reksa dana adalah dana-dana 'mahal' yang dimiliki oleh nasabah besar. Penurunan simpanan nasabah di sisi kewajiban dan penurunan kepemilikan obligasi rekap di sisi asset akan membawa konsekuensi logis pada membaiknya loan to deposit ratio (LDR), net interest margin (NIM), dan juga return on asset $(\mathrm{ROA})^{16}$.

Meski terdapat beberapa keuntungan yang mungkin diperoleh bank sebagai penjual, transaksi reksa dana yang dilakukan bank juga memiliki sejumlah risiko potensial. Reputasi bank akan terancam ketika produk reksa dana MI mengalami default (reputation risk), terlebih bilamana MI tersebut adalah private labeled fund yang dibentuk oleh bank itu sendiri (terafiliasi dengan bank). Masyarakat akan mengalami kesulitan dalam mengidentifikasi apakah default tersebut dapat secara penuh dibebankan kepada MI dan atau juga kepada bank

\footnotetext{
14 Restrukturisasi aset perbankan a.l. dilakukan dengan mengurangi pangsa obligasi rekap dalam aktiva mereka. Adapun proses pengurangan obligasi rekap ini dapat dilakukan antara lain dengan cara (i) menjual obligasi rekap yang dimilikinya kepada pihak ketiga bukan bank di pasar sekunder secara tunai (baik secara outright maupun repo), (ii) mengelola penerbitan reksa dana yang di link-kan dengan obligasi rekap miliknya dengan menunjuk Manajer Investasi tertentu (umumnya secara repo), (iii) atau dengan melakukan asset to bond swap (ABS) dengan BPPN.

15 Di mana aset/penggunaan dana yang relatif berjangka panjang (obligasi) akan diselaraskan dengan struktur pasiva/sumber pendanaan yang sebagian besar berjangka pendek (giro, tabungan, dan deposito).

16 Ini merupakan salah satu bentuk accounting engineering.
} 
sebagai last resort (legal risk) ${ }^{17}$. Kedua risiko ini, baik secara terpisah ataupun berbarengan, berpotensi memicu pencairan dana reksa dana secara besar-besaran oleh nasabah (redeem shock) yang pada gilirannya akan mengancam likuiditas bank (liquidity risk) ${ }^{18}$. Selain itu, risiko redeem ini juga sangat mungkin timbul di tengah-tengah perubahan kondisi di pasar keuangan yang signifikan (market risk), termasuk misalnya sebagai akibat perubahan (arah) perkembangan suku bunga instrumen moneter yang mendadak dan bergejolak.

Intensitas kedua jenis risiko di atas terkait erat dengan keberadaan dua variabel, yakni (i) bagaimana hubungan antara bank dengan MI-apakah terafiliasi ataukah independen dari bank dan (ii) bagaimana skim perjanjian kerja sama antar keduanya. MI yang terafiliasi dengan bank akan memperbesar kedua jenis risiko. Terutama terkait dengan bank yang melakukan product mix, sebuah pertanyaan krusial yang muncul adalah apakah bank melakukan perjanjian transaksi jual beli obligasi miliknya dengan MI secara outright (jual putus) ataukah repo ${ }^{19}$. Hal ini penting karena transaksi repo dikuatirkan masih akan meninggalkan risiko (kontinjen) bagi bank.

Mengingat reksa dana dewasa ini didominasi reksa dana dengan underlying portfolio obligasi pemerintah, masalah pricing obligasi menjadi isu lain yang perlu diperhatikan. Bapepam sampai dengan saat ini belum mengeluarkan aturan penentuan harga obligasi. Harga obligasi pada saat pembelian kembali oleh bank akan sangat tergantung pada kebijakan penentuan harga yang digunakan oleh MI, apakah marked to market (misalnya atas dasar weighted average price BES selama hari kerja, atau bisa juga atas dasar last price done), amortization (diamortisasi sampai dengan maturity), ataupun cara lainnya. Selain berisiko bagi bank, belum adanya aturan penentuan harga ini juga sangat potensial merugikan nasabah pembeli produk reksa dana terutama ketika mereka ingin mencairkan reksa dana mereka.

Selain itu, kecenderungan bank-bank nasional untuk melakukan praktek copy-paste produk perbankan yang dianggap sukses membawa risiko reksa dana dari risiko individual bank menjadi risiko sistemik perbankan. Default-nya satu atau beberapa produk reksa dana yang dijual oleh satu bank kemungkinan dapat merembet pada pencairan besar-besaran (redeem shock-rush) pada produk reksa dana yang dijual oleh bank lain. Kesulitan likuiditas yang semula dihadapi oleh (sejumlah) individu bank pada gilirannya berpotensi mengancam gejolak sistim perbankan (domino effect).

17 Dalam perkembangannya, untuk meningkatkan popularitas produk reksa dana, sebuah bank bahkan berani memberikan semacam return guarantee kepada nasabah atas produk reksa dana yang mereka beli dari MI. Garansi tersebut dituangkan dalam sebuah statement of account. Namun mekanisme semacam ini sepatutnya dilarang karena menyisakan risiko bagi bank ybs. Apalagia/d kode etik MI tidak diperkenankan menjamin return.

18 Ancaman ini masih ada meski ada ketentuan bahwa nasabah hanya dapat mencairkan produk reksa dana mereka dalam prosentase tertentu per hari. Dari sisi legal sebenarnya bank penjual sama sekali tidak terpapar risiko likuiditas.

19 Nama lain dari perjanjian atas dasar repo adalah stand by buyer. Namun, ini pada dasarnya tidak berbeda dengan repo karena setiap terjadi redeem selalu dibeli oleh Bank. 


\section{Moneter}

\section{Isu Statistik Moneter}

Satu isu yang menjadi perdebatan awal terkait dengan kegiatan reksa dana melalui perbankan adalah pendapat yang menyatakan bahwa dana hanya mengalir dari satu bank ke bank lain. Atau dengan penyederhanaan transaksi, aliran dana hanya berpindah dari tabungan (SD) atau deposito (TD) milik nasabah ke bentuk giro bank (DD) yang lebih likuid milik MI (di bank yang bersangkutan atau di bank yang berbeda) ${ }^{20}$. Pendapat ini, bila benar, membawa sebuah konsekuensi logis bahwa penurunan SD/TD di satu bank akan meningkatkan DD di bank tersebut atau bank lain, sehingga secara agregat makro tidak terjadi aliran dana keluar dari sistim perbankan.

Hanya pendapat di atas ternyata belum mampu didukung oleh data perbankan secara keseluruhan (Grafik 2) ${ }^{21}$. Dengan menggunakan satu titik ekstrim di bulan Juli 2002 sebagai ilustrasi ${ }^{22}$, seiring dengan kenaikan dana kelolaan reksa dana sebesar Rp6,6 triliun, statistik tabungan-deposito dan giro juga mengalami kenaikan masing-masing sebesar Rp5,1 triliun dan Rp1,2 triliun ${ }^{23}$. Mengapa pendapat di atas sulit dijustifikasi dengan data? Jawaban pertama kemungkinan terkait dengan kenyataan bahwa sifat data statistik yang saat ini dimiliki dan digunakan adalah data stock, bukan data flows. Data stock yang berasal dari laporan bulanan bank umum (LBU) hanya menangkap data posisi akhir bulan, tanpa bisa mengungkapkan mutasi-mutasi harian yang terjadi $(\text { flows })^{24}$.

\section{Grafik 2.}

\section{Perubahan nominal Simpanan Masyarakat dan Reksadana}

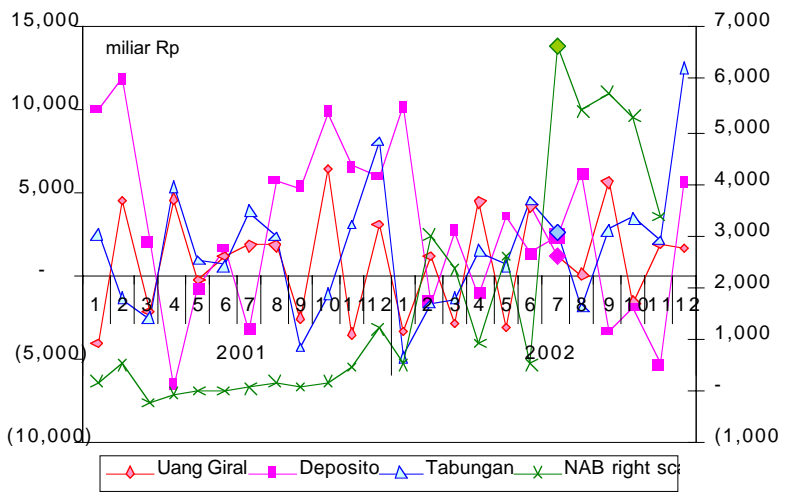

20 MI aktif melakukan transaksi beli-jual di pasar sekunder, sehingga membutuhkan rekening yang likuid dan transferable seperti halnya giro.

21 Monetary survey sebagai sumber data.

22 Pada waktu itu, dana kelolaan reksa dana mencatat kenaikan tertinggi.

23 Untuk timeframe (triwulanan) yang lebih panjang, kondisi ini tetap valid

24 Selain masalah timing (kapan transaksi terjadi dan kapan pencatatan dilakukan), struktur portfolio reksa dana menjadi isu lanjutan. Sebagai ilustrasi, bila MI melakukan investasi pada saat IPO, yang terjadi adalah mirip-mirip penyaluran kredit/ pembiayaan, yang kemudian alirannya sebagian akan masuk kembali ke perbankan walau mungkin tidak one to one. 
Kemungkinan jawaban kedua terkait dengan isu potensi larinya dana reksa dana ke luar negeri, yang pada gilirannya akan mengurangi dana yang ada di dalam sistim perbankan di Indonesia. Meski sejumlah prospektus produk reksa dana belum mencantumkan penanaman di luar negeri dalam portfolio-nya, langkah ini mungkin terjadi mengingat peraturan Bapepam telah mengizinkan reksa dana berinvestasi ke luar negeri sebesar 15\% dari NAB mereka. Dalam kaitan ini, dampaknya secara makroekonomi diperkirakan kurang lebih sama dengan dampak capital flight. Namun dalam praktek, mengingat penempatan dana pada aset di luar negeri dewasa ini menghasilkan return yang jauh lebih rendah dari aset rupiah dan terlebih lagi terkena currency risk, hal ini kemungkinan besar belum terjadi.

Namun, argumen berikut diyakini dapat membantah pendapat di atas. Meski pencatatan LBU menunjukkan telah terjadi aliran dana keluar dari sistim perbankan, dana tersebut sejatinya secara fisik tidak keluar dari sistim. Muara aliran dana (end game) transaksi reksa dana kemungkinan besar tidak lagi tercatat di perbankan, meski transaksi tersebut dilakukan melalui perbankan,. Untuk memperjelas argumen di atas, terlebih dahulu perlu dicermati tentang (i) apa peran bank kustodian, dan (ii) bagaimana dan di mana perlakuan pencatatan transaksi reksa dana.

Sesuai ketentuan yang berlaku, kegiatan transaksi reksa dana tidak serta merta tercermin dalam neraca bank kustodian ${ }^{25}$. Hal ini dikarenakan lembaga kustodian hanya bertindak sebagai administrator untuk manajer investasi-antara lain dengan memberikan jasa penitipan efek sehubungan dengan kekayaan reksa dana, menyimpan catatan secara terpisah dari sisi kewajiban reksa dana ${ }^{26}$, mewakili pemegang rekening yang menjadi nasabahnya, termasuk menghitung Nilai Aktiva Bersih per unit penyertaan reksa dana setiap hari $^{27}$. Dengan demikian, semua harta dan kewajiban reksa dana itu tidak muncul di neraca bank kustodian, baik secara on ataupun off-balance sheet.

Di luar masalah ketentuan tersebut di atas, mengingat bahwa reksa dana adalah suatu bentuk hukum tersendiri, baik harta maupun kewajiban reksa dana adalah milik reksa dana itu sendiri, bukan milik bank kustodian dan sama sekali terpisah dari laporan keuangan $\mathrm{MI}^{28}$. Kondisi ini menyiratkan bahwa transaksi reksa dana sudah terlepas dari pembukuan bank yang menjadi subyek pelaporan (LBU). Di sinilah terjadi fenomena

25 Keputusan Ketua Bapepam No. Kep-15/PM/2002 tanggal 14 Agustus 2002, peraturan No. IV.B.1 tentang Pedoman Pengelolaan Reksa Dana Berbentuk Kontrak Investasi Kolektif (KIK). Hampir seluruh reksa dana yang ada saat ini berbentuk KIK.

26 a.l. menunjukkan semua perubahan dalam jumlah unit penyertaan berikut data administratif terkait dengan kepemilikan unit penyertaan.

27 Data Nilai Aktiva Bersih (NAB) digunakan untuk menunjukkan performance dari manajer investasi dan reksadana yang bersangkutan.

28 Sesuai UU No.8 tahun 1995 tentang Pasar Modal 
missing money sebagai akibat belum diperhitungkannya neraca reksa dana sebagai salah satu komponen uang beredar.

Fenomena tersebut di atas terjadi baik pada bank yang hanya menjadi penjual maupun yang mengaitkan langsung dengan produk bank (lihat skema halaman 4-5, neraca posisi setelah reksa dana), sebagai akibat dari menurunnya dana masyarakat di sisi pasiva perbankan-dari sisi komponen-dan menurunnya obligasi rekapitalisasi milik perbankan-dari sisi faktor NCG. Sementara itu, kenaikan kewajiban produk reksa dana terhadap investor belum diperhitungkan. Dengan kata lain, meski secara agregat likuiditas perekonomian baik secara nominal maupun riil sebenarnya tidak mengalami penurunan, pencatatan statistik uang beredar yang dilakukan dewasa ini tidak mampu "menangkapnya" dan karenanya dapat digolongkan understated.

Menilik perkembangan di atas, langkah pendefinisian kembali indikator uang beredar menjadi semakin mendesak untuk dilakukan. Meski kemungkinan semakin kehilangan fungsinya sebagai sasaran moneter, besaran moneter secara umum masih dapat difungsikan sebagai leading information terhadap perkembangan konsumsi masyarakat kedepan dan karenanya juga inflasi ${ }^{29}$. Sebagai informasi, reksa dana menjadi salah satu bagian penting dalam salah satu pendefinisian uang beredar versi Federal Reserve. Istilah MZM atau Money of Zero Maturity mencakup besaran checking account, saving deposit, dan money market mutual fund (reksa dana pasar uang) ${ }^{30}$. Indikator ini dalam spektrum agregat moneter mempunyai cakupan yang sedikit lebih luas daripada M1-karena penghitungan indikator ini memasukkan besaran produk reksa dana pasar uang, namun lebih sempit daripada M2. Indikator ini antara lain berfungsi sebagai indikator awal atas kemungkinan peningkatan transaksi masyarakat, yang pada akhirnya bermuara pada munculnya tekanan pada harga dan output. Collins dan Edwards (1994) dalam salah satu papernya bahkan mengusulkan perlunya perluasan M2 dengan menambahkan reksa dana saham dan obligasi yang dimiliki oleh rumah tangga ${ }^{31}$.

29 Apalagi bila ditilik secara teoritis uang beredar dalam arti luas (broad money) layaknya mengukur karakteristik 'store of value' dari uang. Oleh karena itu, mengingat simpanan rumah tangga mewakili konsumsi yang ditangguhkan, selayaknya broad money mampu memberi leading information terhadap konsumsi ke depan, hence, inflasi. Lihat Recent Developments in the Monetary Aggregates and Their Implications (Bank of Canada Review, Spring 2000), Money and Financial Markets (Federal Reserve Bank of Cleveland several issues).

30 Term MZM ini pertama kali disampaikan oleh Poole (1991), didasari oleh pemikiran Friedman dan Schwartz (1970) bahwa uang adalah 'temporary abode of purchasing power'. Hasil pengujian statistik terhadap MZM dalam 20 tahun terakhir menunjukkan MZM memiliki hubungan yang stabil dengan nominal GDP. Stabilitas ini mendukung paper Motley (1988) dan Poole (1990) yang mengajukan argumen bahwa instrumen moneter dengan zero maturity cenderung lebih terisolasi dari dampak deregulasi dan inovasi finansial.

31 Collins, S., and C.I. Edwards. "An Alternative Monetary Aggregate: M2 plus Household Holdings of Bond and Equity Mutual Funds,” Federal Reserve Bank of St. Louis, Review vol. 76 (November/December 1994) page 7-30. 


\section{Isu Kebijakan Moneter}

Dalam kerangka kebijakan moneter base money targeting yang dewasa ini masih diadopsi oleh Bank Indonesia secara formal, perkembangan reksa dana diperkirakan tidak berdampak secara langsung pada pencapaian sasaran operasional uang primer ${ }^{32}$. Meski pembelian produk reksa dana-dengan nilai nominal mulai dari Rp100.000—dimungkinkan dengan uang tunai (kartal), pembelian investasi di reksa dana baru dewasa ini baru menjangkau kalangan yang terbiasa melakukan transaksi melalui perbankan (banking minded). Namun demikian, perkembangan reksa dana sebagai akibat 'genuine demand'bukan karena kanibalisme dengan produk perbankan seperti saat ini-secara positif potensial mempengaruhi angka pelipat ganda uang (money multiplier) dari besaran uang beredar.

Dalam proses transmisi ke sasaran akhir dengan mempertimbangkan efek tundanya, perkembangan reksa dana secara teoritis dipercaya terjadi melalui jalur harga aset. Setiap perubahan dalam instrumen moneter pada tahap pertama akan mempengaruhi pasar uang, yang pada gilirannya akan diikuti oleh penyesuaian seluruh suku bunga di sepanjang yield curve. Aset dalam bentuk obligasi dengan demikian akan dihargai kembali sebagai akibat dari (i) revisi dalam kupon, dan (ii) revisi dalam ekspektasi penghasilan akibat perubahan harga obligasi. Kondisi ini selanjutnya diterjemahkan ke kegiatan ekonomi riil melalui wealth effect, yang pada gilirannya mempengaruhi permintaan domestik dan akhirnya inflasi. Kecepatan proses transmisi tersebut sangat bergantung pada struktur ekonomi itu sendiri.

Menjadi pertanyaan penting sekarang adalah seberapa besar perubahan instrumen moneter tersebut mempengaruhi permintaan domestik dengan mengubah nilai agregat dari wealth. Jawaban pertanyaan ini sangat terkait dengan seberapa besar proporsi pemegangan aset-aset oleh rumah tangga. Ludvigson (2002) menemukan bahwa dampak perubahan suku bunga fed terhadap wealth hanyalah bersifat sementara, dan akan hilang dalam kurun waktu kurang dari dua tahun. Lettau and Ludvigson (2001) menyatakan bahwa perubahan signifikan pada konsumsi hanya akan terjadi sebagai respons dari perubahan nilai aset yang bersifat permanen. Di Amerika Serikat, yang pasar modalnya sudah sangat berkembang dan setidaknya separuh rumah tangganya memiliki saham, ternyata wealth pasar modalnya pun masih sangat terkonsentrasi (Ameriks dan Zeldes, 2001). Semua ini memberi implikasi bahwa apapun bentuk wealth effect yang terjadi dapat digolongkan relatif kecil karena hanya melibatkan sebagian kecil rumah tangga.

32 Uang primer di Indonesia didefinisikan sebagai (i) uang tunai (uang kartal) yang dipegang baik oleh masyarakat maupun bank umum, ditambah dengan (ii) saldo rekening giro atau cadangan dalam Rupiah milik bank umum dan masyarakat di Bank Indonesia. 


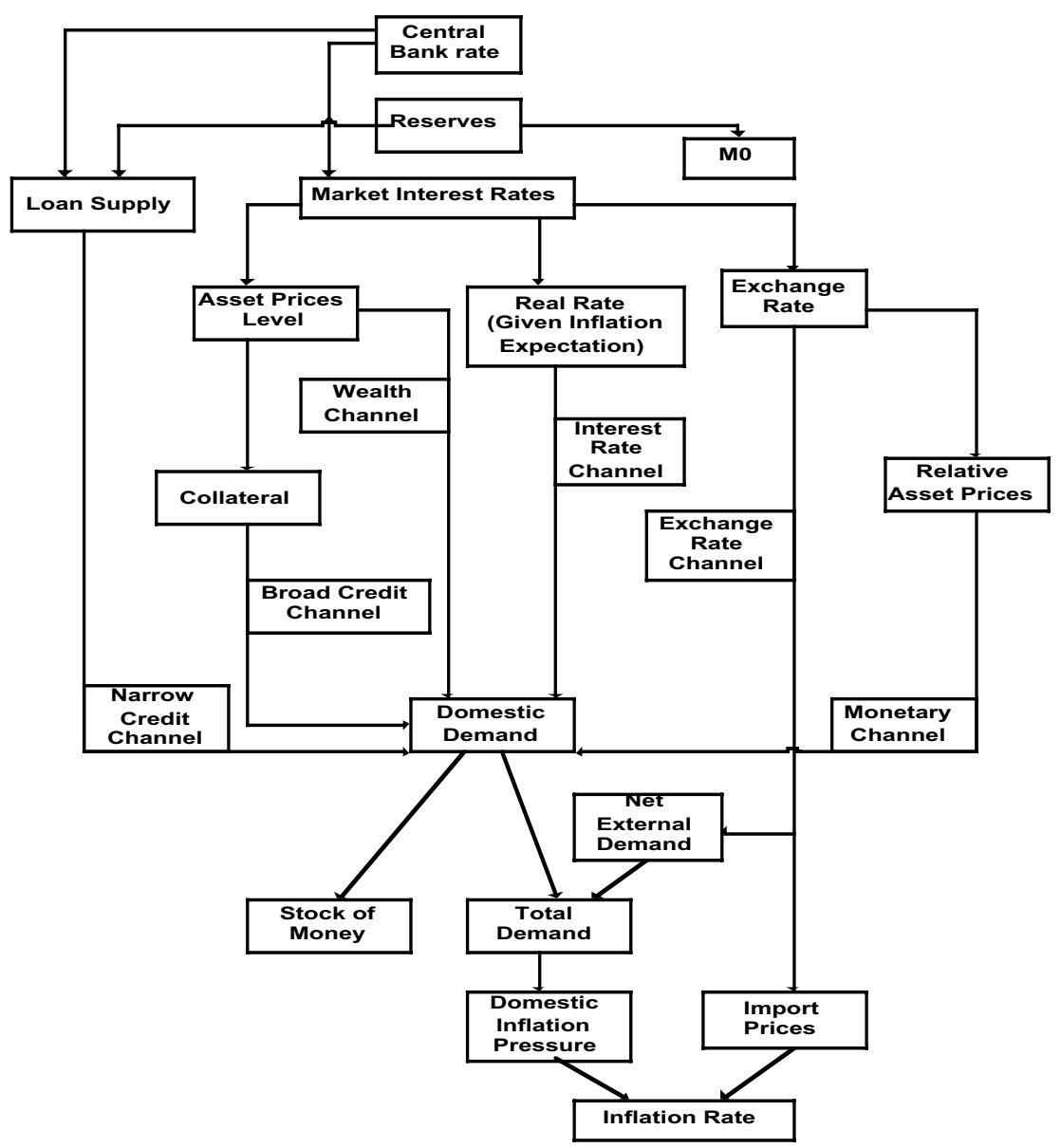

Sumber : Kuttner and Mosser (2002, p. 16) and Bank of England (1999,p.1)

Dalam konteks maraknya reksa dana obligasi pemerintah di Indonesia dewasa ini, skenario transmisi moneter yang mungkin terjadi adalah iSBI $\downarrow \rightarrow \mathrm{p}(\mathrm{A}) \uparrow \rightarrow \mathrm{w} \uparrow \rightarrow \mathrm{D} \uparrow \rightarrow \pi \uparrow$. Penurunan suku bunga instrumen direspons dengan kenaikan harga obligasi yang akan meningkatkan kekayaan rumah tangga. Kondisi ini pada gilirannya akan meningkatkan permintaan domestik dan akhirnya berdampak pada kenaikan harga (inflasi). Namun, menimbang bahwa kepemilikan reksadana dewasa ini baru dienyam oleh sebagian kecil masyarakat perkotaan yang berpendidikan relatif tinggi dan sekaligus banking minded, wealth effect dari maraknya reksa dana akhir-akhir ini diprakirakan masih sangat kecil.

Terkait dengan pelaksanaan kebijakan moneter, mengingat bahwa perkembangan reksa dana-khususnya dengan underlying obligasi pemerintah-terkait erat dengan kecenderungan penurunan suku bunga SBI akhir-akhir ini, perkembangan reksa dana dengan demikian sangat rentan terhadap perubahan stance kebijakan otoritas moneter. Secara 
lebih spesifik, perubahan stance kebijakan otoritas moneter, terlebih yang dilakukan secara mendadak dan dalam magnitude besar (bergejolak), sangat membahayakan perkembangan reksa dana khususnya dan kestabilan pasar keuangan secara umum. Perubahan stance kebijakan moneter dalam kaitan ini perlu dilakukan secara gradual, terukur, dan konsisten (smooth). Pertimbangan inilah yang menjadi dasar utama mengapa bank-bank sentral di dunia umumnya menerapkan kebijakan interest rate smoothing ${ }^{33}$.

Dalam konteks kondisi perekonomian Indonesia dewasa ini, maraknya fenomena reksa dana yang melibatkan perbankan ini dapat menjadi salah satu indikator dari masih belum pulihnya aliran dana-dana perbankan dalam bentuk kredit ke sektor riil. Besarnya ketertarikan perbankan di bisnis reksa dana dikuatirkan justru akan makin mempertebal keengganan bank-bank untuk menyalurkan kredit ke sektor riil yang secara umum masih dipandang penuh risiko. Satu efek positif dari fenomena "disintermediasi" perbankan ini adalah munculnya dorongan yang semakin kuat bagi perusahaan-perusahaan untuk mengurangi ketergantungan mereka pada dana perbankan dengan menerbitkan obligasi. Terutama guna memahami dampaknya pada mekanisme transmisi kebijakan moneter. otoritas moneter sangat berkepentingan untuk mencermati kemungkinan perubahan struktural di pasar keuangan Indonesia ini.

\section{Keuangan Pemerintah}

Pertumbuhan produk reksa dana sangat kondusif bagi pengembangan pasar obligasi pemerintah, baik di pasar perdana maupun sekunder. Pembebasan PPh untuk reksa dana dapat dianggap sebagai salah satu cara untuk memuluskan jalan bagi terbentuknya pasar sekunder obligasi pemerintah yang deep dan likuid yang pada gilirannya mendorong yield

\section{Grafik 3.}

\section{Perkembangan YTM beberapa Fixed Rate Bonds dan Suku Bunga SBI}

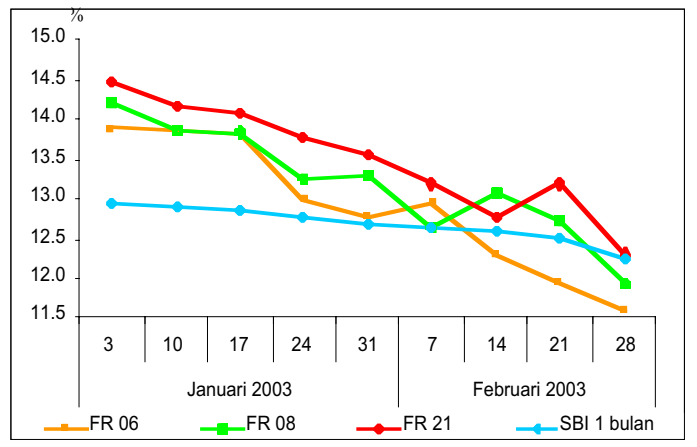

33 Lihat Srour, Gabriel (2001), "Why Do Central Banks Smooth Interest Rates”, Bank of Canada, Working Paper 2001-17 dan Battelino, Ric et. al, "The Implementation of Monetary Policy in Australia", Reserve Bank of Australia, Research Discussion Paper 9703 
to maturity (YTM) menjadi lebih rendah ${ }^{34}$. Dengan YTM yang lebih rendah, penghematan keuangan pemerintah yang bisa dihasilkan dari penerbitan obligasi untuk keperluan refinancing selama setahun diperkirakan dapat mencapai Rp35 triliun, jauh lebih besar daripada tax-revenue loss kurang lebih sebesar Rp1 triliun akibat pembebasan PPh final tersebut di $\operatorname{atas}^{35}$. Grafik 3 mengindikasikan bahwa sejumlah obligasi pemerintah yang aktif diperdagangkan, seperti FR 06, FR 08 (obligasi rekap) dan FR 21 (T-bonds), mempunyai pergerakan YTM yang semakin menurun tajam. Per akhir Februari 2003, YTM obligasi seri FR 06 dan FR 08 bahkan telah mencapai level di bawah suku bunga SBI 1 bulan.

\section{PENUTUP}

Salah satu kesulitan mendasar dalam pengawasan dan pengaturan perkembangan reksa dana adalah bahwa produk reksa dana berada pada dua wilayah yurisdiksi yang berbeda, yakni industri perbankan dan pasar modal. Meski produk reksa dana sendiri secara formal merupakan produk pasar modal, keterlibatan bank dalam transaksinya berpotensi menimbulkan sejumlah risiko. Guna meminimisasi risiko yang mungkin terjadi namun tanpa mengorbankan keuntungan yang potensial diperoleh dari perkembangan reksa dana (pendapatan tetap), kerja sama antara otoritas moneter dan otoritas pasar modal sangat diperlukan. Dipertegasnya aturan transaksi jual beli obligasi rekap antara bank dan MI untuk lebih menekan risiko bank adalah salah satu bentuk kerja sama tersebut ${ }^{36}$. Selain itu, peran regulator dan perbankan perlu ditekankan dalam mengedukasi masyarakat bahwa reksa dana adalah produk pasar modal yang memiliki risiko investasi tersendiri. Termasuk dalam upaya edukasi ini adalah dihapuskannya seluruh bentuk garansi atas return reksa dana oleh perbankan ${ }^{37}$. Terakhir, otoritas pasar modal juga perlu menyusun aturan pricing obligasi untuk melindungi kepentingan semua pihak yang bertransaksi, termasuk masyarakat sebagai nasabah.

\footnotetext{
34 Sebelum muncul kebijakan ini, YTM obligasi rekap berada pada kisaran 24\% sehingga menyebabkan tipisnya permintaan terhadap obligasi jenis ini.

35 Hasil perhitungan kasar dari P.T. Schroders Investment Management Indonesia.

36 Secara khusus, aturan tersebut menyatakan bahwa hanya transaksi outright yang dimungkinkan dan diterapkan peraturan prudential yang berlaku terhadap MI yang terafiliasi dengan bank.

37 Baru-baru ini Bapepam menyatakan bahwa produk reksadana tidak termasuk produk dalam penjaminan pemerintah.
} 


\section{DAFTAR PUSTAKA}

Bank of England Monetary Policy Committee. 1999. “The Transmission Mechanism of Monetary Policy." London: Bank of England.

Battelino, Ric et. al, "The Implementation of Monetary Policy in Australia", Reserve Bank of Australia, Research Discussion Paper 9703.

Collins, S., and C.I. Edwards. 1994. "An Alternative Monetary Aggregate: M2 plus Household Holdings of Bond and Equity Mutual Funds," Federal Reserve Bank of St. Louis, Review vol. 76 (November/December 1994) page 7-30.

Kuttner, K.N., and P.C. Mosser.2002. "The Monetary Transmission Mechanism: Some Answers and Further Questions." Federal Reserve Bank of New York Economic Policy Review.

Ludvigson, Sidney et.al. 2002. "Monetary Policy Transmission through the Consumption-Wealth Channel." Federal Reserve Bank of New York Economic Policy Review

Mishkin, cF.S. 1995. "Symposium on the Monetary Transmision Mechanism." Journal of Economic Perspectives.

Srour, Gabriel. 2001. "Why Do Central Banks Smooth Interest Rates", Bank of Canada, Working Paper 2001-17.

.., Indikator Terkini Ekonomi dan Moneter, Bank Indonesia, 1999-2003.

., Laporan Tahunan Surat Utang Negara, Bank Indonesia, Februari 2003.

Money and Financial Markets, Federal Reserve Bank of Cleveland, several issues.

, Statistik Pasar Modal, Riset-Biro PIR Bapepam, beberapa edisi.

Recent Developments in the Monetary Aggregates and Their Implications, Bank of Canada Review, Spring 2000. 


\section{LAMPIRAN}

\section{RE K S A D A N A ${ }^{38}$}

\section{Definisi}

Reksa dana (mutual fund) adalah sertifikat yang menjelaskan bahwa pemiliknya menitipkan sejumlah uang kepada pengelola Reksa dana (Manajer Investasi) untuk digunakan sebagai modal berinvestasi di pasar uang atau pasar modal sesuai dengan kebijakan investasi yang dipilih. Pada prinsipnya, investasi pada Reksa dana adalah melakukan diversifikasi pada sekian alat investasi yang diperdagangkan di pasar modal dan pasar uang, seperti saham, obligasi, commercial paper, dan lainnya.

\section{Landasan Hukum}

- Undang Undang Republik Indonesia No. 8 tahun 1995 tentang Pasar Modal

- Peraturan Pemerintah Republik Indonesia No. 45 tahun 1995 tentang Penyelenggaraan Kegiatan di Bidang Pasar Modal

- Peraturan-peraturan Bapepam

Bentuk Hukum

- Perseroan

- Kontak Investasi Kolektif

Keduanya harus memperoleh ijin dari Bapepam.

Jenis Reksa dana

- Reksadana Pasar Uang (Money Market Fund)

Reksadana ini hanya melakukan investasi pada efek bersifat utang dengan jatuh tempo kurang dari 1 (satu) tahun. Tujuannya untuk menjaga likuiditas dan pemeliharaan modal. Risiko relatif lebih rendah dibanding reksadana jenis lain.

- Reksadana Pendapatan Tetap (Fixed Income Funds)

Reksadana ini melakukan investasi sekurang-kurangnya $80 \%$ dari aktivanya dalam bentuk efek bersifat utang. Tujuannya untuk menghasilkan tingkat pengembalian yang stabil. Risiko relatif lebih besar dari Reksadana Pasar Uang.

38 Sumber: http://www.jsx.co.id/_old/education/reksa.htm, http://www.bankmandiri.co.id/indonesia/company-info/consumer-banking/reksadana.asp 


\section{- Reksadana Saham (Equity Funds)}

Reksadana ini melakukan investasi sekurang-kurangnya $80 \%$ dari aktivanya dalam bentuk efek bersifat ekuitas. Tujuannya untuk memperoleh pertumbuhan harga saham / unit dalam jangka panjang. Risiko lebih tinggi dari Reksadana Pasar Uang dan Reksadana Pendapatan Tetap namun menghasilkan tingkat pengembalian yang tinggi.

\section{- Reksadana Campuran (Discretionary Funds)}

Reksadana ini melakukan investasi dalam efek bersifat saham dan utang yang perbandingannya tidak termasuk Reksadana Pendapatan Tetap dan Saham. Tujuannya untuk pertumbuhan harga dan pendapatan. Risiko moderat dengan tingkat pengembalian yang relatif tinggi daripada Reksadana Pendapatan Tetap.

\section{Manfaat}

\section{- Dapat Diperjual Belikan}

Reksa dana jenis open-end bisa dijual kembali kepada Manajer Investasi, sedang reksadana close-end bisa dijual di pasar sekunder ${ }^{39}$.

- Dikelola Manajemen Profesional Pengelolaan portofolio Reksadana dilaksanakan oleh Manajer Investasi yang dapat melakukan riset secara langsung dalam menganalisa harga efek serta mengakses informasi ke pasar modal.

- Diversifikasi Investasi Akan mengurangi risiko karena dana/kekayaan reksadana diinvestasikan pada berbagai jenis efek sehingga risikonya juga tersebar.

- Kemudahan Berinvestasi Nilai investasi awal reksadana relatif rendah dibandingkan jenis investasi lain.

- Transparansi Informasi Pengelola reksadana wajib mengumumkan Nilai Aktiva Bersih (NAB)-nya setiap hari di surat kabar serta menerbitkan laporan keuangan tengah tahunan

39 Sifat reksa dana:

- Terbuka (open end) Merupakan perusahaan dimana pemodal membeli saham dan menjual kembali kepada perusahaan tersebut, tanpa mengenal batas jumlah saham yang diterbitkan. Transaksi pembelian/penjualan dilaksanakan dengan harga yang dilandaskan pada nilai saat transaksi (current value) yang dalam hal ini disebut sebagai Nilai Aktiva Bersih (Net Asset Value). Perhitungan Nilai Aktiva Bersih dilakukan paling sedikit satu kali sehari dan menunjukkan nilai satu lembar saham di dalam portfolio Reksa dana.

- Tertutup (close end) Merupakan perusahaan Reksa dana yang beroperasi dengan jumlah saham yang tetap dan tidak mengatur secara teratur penerbitan saham baru. Harga saham Reksa dana tertutup ditentukan tidak hanya oleh Nilai Aktiva bersihnya saja, tetapi juga ditentukan oleh permintaan dari penawaran di Bursa. Perusahaan Reksa dana tertutup tidak dapat membeli kembali sahamnya. Jual/beli di lakukan di Bursa atau di luar Bursa.

- Unit Investment Trust Merupakan suatu wahana investasi dimana sponsor Reksa dana (biasanya perusahaan pialang) menempatkan suatu portofolio saham yang tetap secara bersama dengan menyimpannya kepada pihak yang dipercaya (seperti bank), dan kemudian dalam menjual kepemilikan unit-unit dalam portofolio tersebut kepada pemodal (biasanya perorangan). 
atau tahunan serta prospektif secara teratur sehingga investor dapat memonitor perkembangan investasinya secara rutin.

- Likuiditas yang Tinggi Pemodal dapat mencairkan kembali saham/ unit penyertaannya setiap saat sesuai ketetapan yang dibuat, sehingga memudahkan investor mengelola kasnya.

- Biaya Relatif Rendah Karena Reksa dana merupakan kumpulan dana dari banyak pemodal akan menghasilkan efisiensi biaya transaksi.

\section{Risiko}

- Risiko Berkurangnya Nilai Unit Penyertaan Diakibatkan menurunnya harga dari efek (saham, obligasi dan surat berharga lainnya).

- Risiko Likuiditas Penjualan kembali (redemption) sebagian besar unit penyertaan secara bersamaan dapat menyulitkan Manajer Investasi dalam menyediakan uang tunai bagi pembayaran tersebut.

- Risiko Politik dan Ekonomi Perubahan kebijaksanaan di bidang politik dan ekonomi dapat mempengaruhi kinerja perusahaan dan harga efek dalam portofolio

- Risiko Wanprestasi Risiko ini dapat timbul saat perusahaan asuransi yang mengasuransikan kekayaan reksadana tidak segera membayar ganti rugi atau membayar lebih rendah dari nilai pertanggungan.

- Risiko Pembubaran

Pembubaran Manajer Investasi yang penyebabnya bisa datang dari berbagai hal dapat merugikan pemodal.

\section{Memonitor Kinerja Reksa dana}

- Total Hasil Investasi (Total return) Total Hasil Investasi adalah perbandingan antara nilai kenaikan NAB per unit saham/unit penyertaan dalam satu periode dengan NAB per saham/unit penyertaan pada awal penyertaan

- Perkembangan NAB Perkembangan NAB dan tata cara perhitungan besarnya NAB harus dimuat di media massa sehingga memudahkan masyarakat dalam membandingkan kinerja suatu Reksa dana dengan Reksa dana sejenis lainnya.

- Laporan Periodik Pengelola reksadana wajib memberikan laporan periodik (tahunan maupun tengah tahunan) kepada pemegang saham/unit penyertaan yang menggambarkan kinerja reksadana yang bersangkutan. 


\section{Pihak Penunjang Reksa dana}

- Manajer Investasi adalah pihak yang kegiatan usahanya mengelola portofolio efek untuk para nasabah atau mengelola portofolio investasi kolektif untuk sekelompok nasabah kecuali perusahaan asuransi, dana pensiun dan bank yang melakukan sendiri kegiatan usahanya berdasarkan undang-undang yang berlaku

- Bank Kustodian Kustodian adalah lembaga yang memberikan jasa penitipan efek dan harta lain yang berkaitan dengan efek.

\section{Return dari Reksa dana}

Penghasilan investasi reksadana akan sangat bergantung pada prospektus dan jenis reksadana yang dipilih ${ }^{40}$. Secara umum terdapat 3 sumber penghasilan dari investasi pada reksadana:

\section{- Dividen}

Untuk mendapatkan dividen/bunga, pemodal harus memilih reksadana yang memiliki sasaran investasi berupa pendapatan. Manajer Investasi mempunyai hak untuk mendistribusikan atau tidak deviden atau bunga yang diperolehnya kepada pemodal. Kalau prospektusnya menerangkan bahwa dividen/bunga akan didistribusikan, dalam waktu tertentu pemodal akan mendapatkan dividen/bunga tersebut.

- Capital gain

Capital gain akan diberikan oleh reksadana yang memiliki sasaran pertumbuhan. Pendapatan ini berasal dari kenaikan harga saham atau diskon obligasi yang menjadi portofolio reksadana. Bila Manajer Investasi dalam prospektusnya menerangkan akan mendistribusikan capital gain, dalam waktu tertentu pemegang reksadana akan mendapat distribusi capital gain ini. Namun juga terdapat reksadana yang tidak mendistribusikan capital gain, tapi keuntungan tersebut ditambahkan pada NAB.

- Peningkatan NAB (Nilai Aktiva Bersih)

NAB adalah perbandingan antara total nilai investasi yang dilakukan manajer investasi dengan total volume reksadana yang diterbitkannya. Sebagai ilustrasi, pada awal tahun 1990, Manajer Investasi X menerbitkan 445.000 lembar reksadana, dengan harga Rp1.000. Harga ini bisa dianggap sebagai NAB awal. Pada akhir tahun 1990, nilai investasi meningkat menjadi Rp600 juta sebagai akibat kenaikan harga saham yang menjadi portofolio Manajer Investasi X, serta pembayaran dividen dan bunga obligasi. NAB baru adalah Rp600 juta : $445.000=$ Rp1.348. Berarti, reksadana telah mengalami kenaikan

40 Sebagai informasi, setiap prospektus reksa dana akan mencantumkan sasaran investasi pada saat penawaran. Sasaran investasi reksadana adalah pendapatan, pertumbuhan, pertumbuhan dan pendapatan, dan keseimbangan. 
34,8\%. Bagaimana mendapatkan kenaikan NAB tersebut akan sangat bergantung pada jenis reksadana yang dibeli. Reksadana terbuka akan membeli kembali dengan harga NAB baru, sementara reksadana tertutup tidak akan dibeli kembali oleh penerbitnya. Jadi setelah terjadi transaksi di pasar perdana, reksadana tertutup selanjutnya akan diperjualbelikan di pasar sekunder. Harga yang terbentuk merupakan pertemuan dari permintaan dan penawaran. NAB yang diperhitungkan oleh penerbitnya merupakan informasi yang dapat menjadi pedoman tawar-menawar. 